\title{
"What We Have to Be Is What We Are": Re-Discovering an Ontology of Unity in The Asian Journal of Thomas Merton
}

\author{
David Torevell
}

\begin{abstract}
I argue in this article that due to its unique composition and structure, The Asian Journal of Thomas Merton offers readers an opportunity to take part in the monastic tradition of lectio divina. Such meditative reading of the text, besides giving a glimpse into Merton's insights about interfaith living and how monastic identity encourages such a pursuit, also offers the reader an opportunity to reflect on the ontology of unity at the heart of his contemplative theology. I thus wish to suggest that the "ground of openness" that Merton names and exhorts in his work is not simply confined to monastics. My claim is that anyone who has the confidence to read his journal as lectio divina might also come to experience a leaning towards such unity and openness.
\end{abstract}

KEY WORDS: Thomas Merton, Monasticism, Contemplation, Interfaith dialogue, Unity, Communion

It was with the excitement and anticipation of a child setting out on his first holiday that Thomas Merton headed off on his Asian journey in October 1968. This is not wholly surprising, since he had lived as a Trappist monk for 27 years and had rarely left the grounds of the austere monastery called Gethsemani, deep in the heart of Kentucky. ${ }^{1}$ He had

${ }^{1}$ The term "Trappist" refers to the main branch of the Cistercians, that is, the Order of Cistercians of the Strict Observance (O.C.S.O.). This order began in 1892 by the grouping of three congregations who were opposed to any diminution or slackening of monastic practice and customs. Against the backdrop of seventeenth century Gallicanism and Jansenism, the Order aimed to observe the Rule of St. Benedict to the letter and to live a life of dedicated and austere loyalty to his instructions. For good accounts of the significance of The Rule of St Benedict for contemporary culture, see the individual works by Chittister and by Casey. For a comprehensive biography of Merton see Mott. 
been given permission by his abbot, Dom Flavian, to undertake a spiritual pilgrimage to the East. ${ }^{2}$ The spur for the trip had been a conference on monastic renewal in the wake of Vatican Council II, organized by an international Benedictine working group (Aide a l'Implantation Monastique). Merton had been invited to give a keynote address in Bangkok. But his journey was to prove as disastrous as it was exhilarating, for the writer-monk died in Bangkok on December 10, 1968, by electric shock, just after delivering his address. Merton's corpse had to be flown back to America for his solemn requiem mass, much to the grief of his fellow Trappists and all those who had been so deeply influenced by his writings and had grown to love him.

The Asian Journal of Thomas Merton, compiled posthumously, was based on his travel musings and jottings. ${ }^{3}$ It is an eclectic and profound piece of writing, at times witty and whimsical, leaving the reader with a moving and bewildering testimony of his final thoughts about the religious and monastic life. In particular, it discloses his ground-breaking reflections on Christianity's relationship with non-Western world faiths-not only Buddhism but also Hinduism and Islam. What we glimpse through the pages of his journal (a genre he rehearsed in his earlier journal writings, especially in The Sign of Jonas and Conjectures of a Guilty Bystander), is a monk who has little difficulty absorbing into his own Roman Catholic beliefs and practices the spiritual insights and resources of other religions. He always enjoyed reading about and meeting those from other traditions

${ }^{2}$ Dom Flavian was elected Abbot on January 15, 1968 at the young age of 36. Like Merton, he believed his vocation was to live the life of a hermit and after five years as Abbot he returned to this calling. He was therefore a like-minded spirit to Merton and was supportive of his trip to Asia. Besides his endorsement for Merton to speak at the Bangkok conference, he was also keen for him to search for a suitable place to live the life of a hermit on his return, perhaps in California or even Asia, since Gethsemani was becoming, in the wake of Vatican Council II, a place of considerable interest and bustle, and was receiving many visitors. See Hart and Montaldo, Part V, for details of Merton's life as a hermit, and Aguilar, (90-4) for an account of Dom Flavian's election as Abbot of Gethsemane.

${ }^{3}$ The editors of the Journal were Naomi Burton, Patrick Hart and James Laughlin. The consulting editor was Amiya Chakravarty. They worked from three separate notebooks of Merton. The first was a spiral-bound book that Merton intended for publication; the second, a ledger-like volume which, in part, duplicates the first but has some added personal notes; the third was a spiral-bound pocket notebook used for the quick jotting down of summaries of conversations and poems. The final collected edition largely consists of the first notebook since copyright regulations prevented anything from the other notebooks being made public, apart from the poem "Kandy Express" which was taken from his third notebook. For fascinating details of the editing of Merton's journal see Editors' Notes xi-xix of the final edition. 
who had attempted, like himself, to follow a contemplative lifestyle. He had indicated strongly in a letter to John Whitman Sears on November 12, 1962 that he believed "in the importance not so much of abstract notions as of living human dialogue ..." (quoted in Merton, Life 333) when it came to grappling with the opportunities and challenges world faiths present. His Asian journey was a wonderful chance to extend this enjoyment by mutual face-to-face sharing of experience. It was far from usual for Roman Catholic priests to feel so much at home with such matters, even if the scent of aggiornamento, resulting from the second Vatican Council II, was still in the air.

This article tracks some of the key, revelatory moments in this unique literary account. It suggests that Merton's contemplative and monastic formation lies at the basis of his natural attunement to other faiths, and highlights how his creation of a distinctive genre-a form of incisive, but contemplative interfaith travel writing-has much to offer future deliberations on interfaith living and encounter. It also emphasizes that the key to this distinctive living is grounded in an appreciation of an ontology of unity which Merton himself rediscovered in his journey. Anecdotal rather than systematic, episodic more than argumentative, the journal allows readers the opportunity to come up against Merton's thoughts on different faiths as these emerge and then dissolve, an exercise not unlike meditation itself, which allows the mind the freedom to rest on ideas and afterwards naturally and gently allows them to drift away. The result for the reader is a consoling, cumulative renewal of their own heart and mind, as they are put in touch with the profound wisdom of the great world faiths.

Reading Merton's journal, therefore, is more akin to entering a reflective space where one is encouraged to relax and learn the monastic practice of lectio divina, rather than trudging through a well-structured theology textbook on interfaith relations. Such a reading absorbs the unusual rhythms of poetic imagery embedded in the disjointed lines and erratic phrases taken from sacred texts and chance encounters, instead of simply racing through endless words, chapter after chapter, in the hope of finding some systematic resolution of difference and disjuncture. Merton, as a Trappist monk dedicated to following The Rule of St. Benedict knew all too well from personal experience the fruits which came from this spiritual practice of slow, meditative reading; his own life had been transformed by this disciplined exercise. He was aware that The Rule of St. Benedict he so ardently followed encouraged lectio divina several hours each day. ${ }^{4}$

\footnotetext{
${ }^{4}$ Although lectio divina is often associated with a monastic milieu, there has been a
} 
Such slow, contemplative reading takes paradox into its stride and wrestles creatively with divergence and opposition as the ear of the heart listens to the wisdom of a revelatory text. ${ }^{5}$ With this kind of writing, the reader is never worn down by the weight of accumulating information, but encouraged to follow a gentler path-the pondering and chewing over of metaphor and image in small chunks, even when, sometimes, they jolt us into sudden Zen-like insights. In this way, the gaps and silences between the paragraphs not only allow the reader time to consider what has been written, but also carve out a space in the receptive heart to receive and be changed by it. ${ }^{6}$ Questions about ontology and a transformation of consciousness are never too far away from such contemplative exercises, themes I shall explore in more detail later.

Let us begin with some of Merton's reflections on his meetings with the Dalai Lama. These took place at the Dalai Lama's residence in McLeod Ganj, just above Dharamsala. At the first meeting on November 4, they discussed religion and philosophy and, in particular, dzogchen, the "great perfection." As Aguilar notes,

Merton's knowledge of Tibetan Buddhism must have been good because of the in-depth nature of their discussion of the Buddhist notion of dzogchen, the great way of all-inclusiveness, the esoteric tradition of the Nyingmapas order of Tibetan Buddhism, a tradition which goes back to the eighth century, when great teachers such as Guru Padma Sambhava (Swat Valley) and Vimalamitra (India) visited Tibet. (Aguilar 100)

Merton also mentions how during the second meeting, the one on November 6 , they dealt with the generic notion of monasticism and its bearing on the transformation of consciousness. He records: "I said it was important for monks in the world to be living examples of the freedom and transformation of consciousness which meditation can bring" (Asian Journal 112). For many years Merton had been reflecting and writing about what and who a monk actually is, what kind of monastic consciousness

recent revival in its importance for all people of faith. In 2005 Pope Benedict XVI publicly recommended the practice to everyone since it "brings about that intimate dialogue in which the person reading hears God who is speaking, and in praying, responds to him with trusting openness of heart. If the practice of lectio divina is effectively promoted, I am convinced that it will bring to the church a new spiritual springtime" (5). See Foster's works and also Masini's for particularly astute accounts of the practice.

${ }^{5}$ See Howe for an excellent account of the importance of the heart in monasticism.

${ }^{6}$ See my article "Circles of Meaning," which expounds on the significance of the Latin word considerate. 
is sought and how he might relate to the world; ${ }^{7}$ here he was able to share his thoughts on the exemplar and archetype of the monk and to listen to fellow monastics as they teased out common ground on the issue. What seemed to matter here was monastic identity, not Christian or Buddhist identity. What also particularly attracted Merton at the second meeting was the way in which the Dalai Lama expressed the synergy between contemplation and action, or as Merton expressed it, "He insists on detachment, on an 'unworldly life,' yet sees it as a way to complete understanding of, and participation in, the problems of life and the world" (113). Then appears the teaching which is evidently common to both men: renunciation and detachment must come first-appropriate action then follows. ${ }^{8}$ Like monastic identity, this connection between action and contemplation was something dear to Merton's heart. The meeting also addressed issues of the mind and meditation and the different bodily and hand positions Tibetan and Zen Buddhist practices adopt. Their third meeting on November 8 raised discussion about Marxism and the points of connection between this philosophy and religious philosophy, a theme Merton would address in some detail in his final talk in Bangkok.

But even before this exchange, one can read in the Journal a self-contained, poetic interlude, a glimpse of beauty for the reader's own contemplation, an opportunity again to practice lectio divina:

Two white butterflies alight on separate flowers. They rise, play together briefly, accidentally, in the air, then depart in different directions.

And a little later comes Merton's admiration for a Hindu poem about Krishna:

I would set fire to my house

for him. I would bear

The scorn of the world.

He thinks his sorrow is joy

When I weep, he weeps.

${ }^{7}$ For a useful summary of Merton's writings on the nature and identity of a monk, see (O'Connell 306-9).

${ }^{8}$ Merton's book Contemplation in a World of Action was published posthumously, but was put together by him before he died. The relationship and dynamic between these two areas was never far from his thinking throughout his life, and Merton's political activism is testimony to this. He often spoke about himself as "a man in the world" and was conscious that he was a contemporary of Auschwitz, Hiroshima, Vietnam and the Watt riots. See (Shannon, Bochen and O'Connell 84-7) for further details. 
When the sound of your flute reaches my ears

it compels me to leave my home, my friends,

it draws me into the dark towards you.

Such poetic interludes alert the reader to the spiritual insights which come from living contemplatively in the present moment and importantly, to an original unity underlying all difference.

\section{CONTEMPLATIVE COMPARATIVE THEOLOGY}

Throughout the Journal, Merton offers comparisons between the different forms that religions use to assist spiritual ascent, highlighting conceptual bridges between different faiths' beliefs and practices. Let us look at one example. His attraction to Murti's discussion of tantra with its combination of "mantra, ritual, worship and yoga" (Asian Journal 113) triggers comparisons in Merton's mind with Christian theologians' insights into similar matters. He notes, "I am left musing on St. Irenaeus, St. Gregory of Nyssa, the catechesis of St. Cyril of Jerusalem, early Christian liturgy, baptism, and Eucharist as initiation into the Pascha Christi" (113). And so too, perhaps, is the reader. The meaning is clear: religion itself uses its manifold forms wisely, neither exhausting nor reducing the Absolute to its own level. Rather, religion raises humanity in its journey to "absolute" truth by "conventional" means and, by doing so, avoids the risk of idolatry. Such forms, including religions' teachings, are important, but serve as vehicles and nothing more. Or as Merton's Vietnamese Buddhist friend, Thich Nhat Hahn, puts it, "The Buddha regarded his own teaching as a raft to cross the river and not as an absolute truth to be worshipped or clung to" (123).

A little later a further Buddhist-Christian comparison alludes to Marco Pallis's discussion of the Buddha's touching of the earth. ${ }^{9}$ Like Jesus overcoming Satan in the wilderness, the Buddha feels the earth to claim his authority over it, and to prevent Mara from stealing it as his own. With his other hand, the Buddha holds out a begging bowl to receive the gift of grace. Merton speaks about the gift of grace so naturally within a Buddhist context that one is drawn into the unusual claim and encouraged to reflect on this comparison by means of the image of the two gestures. He then offers a teaching, bold in its claim, based on the image: "An active attitude toward the world and a passive attitude toward heaven. The

${ }^{9}$ Merton's reflection here is taken from his reading of Marco Pallis' article, "Is There Room for Grace in Buddhism?" 
ignorant man does the opposite: he passively accepts the world and resists grace, gift and heaven" (114).

\section{LIVING AN INTERRELATION}

Merton's Asian writings, therefore, teach religions' wisdom by their astute and seamless comparisons of Eastern insights with Christian counterparts. Often this feels more like a gentle, poetic reflection within which a teaching naturally emerges, rather than a strident homily. Such spiritual counselling does not always come easily to Merton however, and the admission of his own (and perhaps the reader's) wrestling with the philosophical contradictions he finds himself having to face on his journey are told honestly. For example, one episode tells of his ride in the Dalai Lama's jeep wearing the snow-white robe and black scapular of the Cistercian Order to which he belongs. This occasions Merton's musings about "living an interrelation but on my own terms" and appearing as an "American lama." But he still acknowledges that he wishes to assume the identity of a tourist rather than a "monk, a priest, a cleric, in "the world' since 'it is less offensive"' (Asian Journal 16). Such sections about the complexities of interfaith exchanges are often interwoven with reflective and poetic descriptions; for example, after the jeep ride he mentions the sounds and sights of the landscape within which he finds himself that serves as a meditation in itself:

A drum in the village, with an erratic beat; and before, shrill, enthusiastic brass getting nowhere. Cries of children nearer the house. Light of setting sun on the brown mountain side. A long, quiet meditation.

The journal, too, contains many of Merton's dialogues with people of widely different philosophical beliefs. For example, on November 7, Merton writes his own reflections on the French philosopher Herbert Marcuse's critique of "mass culture." Marcuse, as a university professor, had been hugely influential on young people since he had taken part in many student protests against capitalism in the 1960 s. $^{10}$ Merton prefaces his comments on Marcuse with a meditation on the contemplative life itself which

${ }^{10}$ Merton had a very positive attitude towards the work of the neo-Marxist Herbert Marcuse whose book One-Dimensional Man dealt with the issue of alienation, a theme which Merton himself was drawn to in the early Marx. Merton went as far to suggest that Marcuse's position on this matter was closer to a monastic perspective than many theologians he had read. 
he hints allows a space of liberty in which new possibilities can surface. He suggests that through contemplation there arises a new experience of time, not a stop-gap stillness, but a "temps vierge." This phrase, untranslated by Merton, was used in his earlier work Conjectures of a Guilty Bystander to describe the beginning of a new day when the "first chirps of the waking day mark the 'point vierge' of the dawn under a sky as yet without real light, a moment of awe and inexpressible innocence ..." Merton uses the phrase to indicate that vital moment when we ourselves might ask if it is for us to "be" each day: "He answers 'yes.' Then, they one by one wake up, and become birds.... Presently they will be fully themselves, and will even fly" (note 32,117 ).

Merton advises that this crucial "temps vierge" must not become dominated by one's own ego; rather, it must be "compassionate time," rooted in a sense of "common illusion and in criticism of it" (Conjectures 117). This triggers an analogous reflection on Marcuse's notion of culture as anti-culture. Mass culture stifles creativity due to the sheer mass of what is produced. As a result, poetry should start with an awareness of this contradiction and use its strengths as anti-poetry since it is able to draw freely on the "superabundant nonsense at its disposal"; as Merton concludes, "One no longer has to parody, it is enough to quote-and feed back quotations into the mass consumption of pseudo-culture" (118). He then draws a comparison between Marcuse's philosophy and the aim of the Buddhist madhyamika system of thought. ${ }^{11}$ The method recommended is to show an opponent the absurdity of his position based on arguments accepted by him. If he still does not accept the implications, then that is "his problem."

In places the Journal makes comparisons between Christianity and Eastern religious practices which are weighted in favour of the latter. On November 7 he records how his encounters with Buddhists have been on a deep level and is pleased that each adherent sees in the other a "certain depth of spiritual experience, and it is unquestionable" (124). But he also records at this point that Buddhists seem to have a deeper attainment and certitude than Catholic contemplatives (124). This intermingling of religious identities is a strong feature of the Journal. Merton tells of a

${ }^{11}$ Merton writes in his Journal the following: "Madhyamika does not propound 'another truth.' It is content to reduce 'the opponents' position to absurdity on principles and consequences which the opponent himself would accept.' If he does not in fact accept them in this form the logic of his position demands their acceptance. But then, argument is at an end. The purpose of Madhyamika is not to convince, but to explode the argument itself. Is this sadism? No, it is compassion! It exorcises the devil of dogmatism" (118). 
dream he had when he saw himself back at Gethsemani abbey wearing a Buddhist robe, "but with more black and red and gold, a 'Zen habit,' in color more Tibetan than Zen." And on November 16 he records his meeting with Chatral Rimpoche who had meditated in solitude for thirty years and had still not attained to perfect emptiness (143). He writes how the conversation centred around dzogchen and comparative points of Buddhist and Christian doctrine, including "the Risen Christ, suffering, compassion for all creatures and motives for 'helping others,'-but all leading back to dzogchen, the ultimate emptiness ..." (143). Merton then hears Chatral call him a rangung Sangay, a "natural Buddha" and how they might reach complete Buddhahood in their next life, or even in this life if they practised renewed dedication to the path.

For Merton, this easy linguistic and existential moving in and out of two or three religious worlds during his Asian trip was a natural consequence of the monastic formation he had been subject to for many years. His reading of Eastern religious texts had been highly influential during his time at Gethsemani. It was no real surprise for Merton to experience on his journey that Christian and Buddhist monks were concerned with similar things; Merton felt at home with fellow practitioners of meditation and silence. In a letter he wrote to friends from Asia in November 1968, he records how in particular Buddhist monks "... are specialists in meditation and contemplation. This is what appeals to me most. It is invaluable to have direct contact with people who have really put in a lifetime of hard work in training their minds and liberating themselves from passion and illusion .... Talking with them is a real pleasure" (Asian Journal 386). Because Merton was so steeped in his own tradition he was able to be free and open to others. Indeed, in 1967, Amiya Chakravarty, a Hindu scholar, who admired Merton and was with him for part of his Asian journey, wrote to him that, "the absoluteness of your faith makes you free to understand other faiths" (quoted in Shannon 214).

On November 18 Merton re-thinks his journey so far, what he calls a "reassessment of the whole Indian experience in more critical terms" (Asian Journal 148). He admits that he had been looking for something, an answer, a vision, "something other," but this he knows often leads to illusion, the illusion that there is something else. He chides himself for still hankering after "Differentiation-the old splitting-up process that leads to mindlessness, instead of the mindlessness of seeing all-in-emptiness and not having to break it up against itself" (148). Recognizing the Buddhist concept of sunyata, the essential unity of all things, he believes, is one way forward. But at the same time, he admits that he has no desire to settle 
in the East or in India as a hermit; indeed, what his Asian trip reaffirmed was the realization that Gethsemani was his beloved monastery and that "being away has helped me see it in perspective and love it more" (149). There were never any thoughts recorded about conversion to Buddhism or Hinduism; but what did happen during his time away was a deepening of monastic identity and for Merton this was always rooted in Catholic Christianity, even if it was of a very different kind to many Catholics at the time..$^{12}$ It is significant that throughout the Journal Merton jots down when and where he was able to say mass; the celebration of the eucharist continued to be an important aspect of his spiritual practice (254).

Merton had no illusions about facile acceptance of different religious world views. In the notes he wrote before his Calcutta talk in October 1968, he named five matters which were indispensible for guiding his interfaith dialogues. First, the benefits which come to those who have meditated for long hours and grown accustomed to silence; ${ }^{13}$ second, the need to avoid false syncretism; third, respect for the deep differences across religious traditions; fourth, the avoidance of giving too much attention to external matters like institutional arrangements and monastic rules; and fifth, an emphasis on self-transcendence and the importance of changing consciousness (Shannon 163). These five things are foundational in understanding Merton's encounter with world faiths.

\footnotetext{
${ }^{12}$ Merton believed that Vatican Council II opened the door for much interfaith encounter and he wished to contribute strongly to the discussion about Christianity's relationship to other world faiths. In Conjectures of a Guilty Bystander he writes, "If the Catholic Church is turning to the modern world and to the other Christian churches, and if she is perhaps for the first time seriously taking note of the non-Christian religions in their own terms, then it becomes necessary for at least a few contemplative and monastic theologians to contribute something of their own to the discussion" (vii).

${ }^{13}$ The importance of going beyond mere verbal communication cannot be emphasized enough in appreciating Merton's understanding of interfaith dialogue. "Communion" rather than communication better explains Merton's ambitions which reflects his common theme to arrive at a fundamental unity between adherents of religious traditions. As he comments in his Calcutta talk, "And the deepest level of communication is not communication, but communion. It is wordless. ... Not that we discover a new unity. We discover an older unity. My dear brother we are already one. But we imagine that we are not. ... What we have to be is what we are." See Merton's essay on "The Awakening of the Inner Self" in the second chapter of The Inner Experience. See also Foster, Deep Calls to Deep for an excellent account of the significance of silence in monastic culture and beyond, and Ford (especially 47-9).
} 


\section{BEING AND UNITY}

No account of Merton's Asian journey would be complete without referring to the experience he had before the great Buddha figures at Polonnaruwa in Sri Lanka on December 1. He had to wait three days before he could commit himself to write anything approaching the significance of this visit. He finally sets down that in seeing these great Buddha statues his pilgrimage had become "clear and purified" (Asian Journal 236). He had now "seen and pierced through the surface and has got beyond the shadow and the disguise." Their aesthetic beauty needed nothing to explain them: "And because it needs nothing it can afford to be silent, unnoticed, undiscovered." Here, Merton disputes with the "doctrinaire" who require justifications and neatly polished argumentation. Conversely, in the stillness and silence of the great smiles of the Buddha images, Merton recognizes a great truth to which he himself aspires-the peace that comes not with emotional resignation or clever justification, but with Madhyamika sunyata-the skill to see "through every question without trying to discredit anyone or anything-without refutation-without establishing some other argument" (233).

What occured at Polonnaruwa was a religious experience as powerful as any he had had within his Catholic monastery in America and he recognized it as something deeply revelatory. He came to see forcibly that the "differentiation" and divisions which separate one religion from another are smashed by discovering the hidden truths the statues represent. "Look at them and a way forward for religion becomes possible," Merton seems to be saying. It is, of course, a mystical understanding borne of years of disciplined prayer and adoration. The images need to be discovered, he exhorted, but they need nothing more than their presence-and it is we, both in the West and in the East, who "need to discover them" (236). By the mid-sixties Merton had written that although as a Catholic he believed his Church would guarantee for him the highest spiritual freedom, he also claimed that the seeking of interior freedom was not confined to Catholicism alone; all respectable religions have this pursuit in common; it would be of no advantage to a Catholic to try to dispute this.

The Buddhist religion had been for some time highly influential on Merton's thinking, especially its Zen form. In 1959 he invited the acclaimed Zen scholar D.T. Suzuki to write a short introduction to a book he was compiling on the desert Fathers, in the sure knowledge that he would discover a Zen quality in them. ${ }^{14}$ Suzuki agreed and in reply Merton wrote

${ }^{14}$ Daisetsu Teitaro (D.T.) Suzuki (1870-1966), a Zen scholar, became one of Merton's closest allies. He taught in Universities not only in Japan but in Europe and the USA. Merton 
poetically about how he sometimes meets his own Zen master in nature itself: "... the other day a bluebird sitting on a fence post suddenly took off after a wasp, dived for it, missed, and instantly returned to the same position on the fence post as if nothing had happened. A brief split-second lesson in Zen" (360). Polannaruwa was another Zen moment.

By December 7 Merton was in Bangkok, preparing to deliver an important lecture for a group of monastics on December 10 which, sadly, was to be his last talk before he died. It was entitled "Marxism and Monastic Perspectives" and his concern was to open up points of dialogue and convergence between Christianity and Marxism. Drawing from the French Marxist Roger Garaudy, he claimed that monks will only be relevant in the world of Marxism in proportion to their keeping hold of their monastic identity. The lecture gave Merton the opportunity to break open publicly again the defining features of monastic identity he had been wrestling with all his life. He writes, "The monk is essentially someone who takes up a critical attitude toward the world and its structures"; he then refers to the students who have taken an analogous critical attitude to the world and, in particular, to a French revolutionary student who claimed "We are monks also" (329). Of course, Merton is well aware of the differences. For example, he is clear that Marxism is foremost about changing economic sub-structures, whereas Christianity seeks to change consciousness itself through an encounter with the Risen Christ. But what we see in this final lecture is how his own of brand of monasticism and of "being a monk" bears directly on his ability to break down the "differentiation" he so wished to erase in his own and in other people's thinking. This is re-emphasized later in this lecture when he talks of Buddhist and Christian monasticism in the same breadth. Comparing the Buddhist notion of ignorance to original sin, he claims that both attack the belief that we are absolutely self-autonomous individual egos. The definitive threads of Merton's lifelong concerns beautifully coalesce in this, his final reflection.

What can we say in summary of the significance of Merton's Asian journey and journal? Clearly, his openness to world religions reflected much of the Roman Catholic theology of religions which was to emerge after Vatican Council II. The two pivotal conciliar documents Nostra Aetate

had hoped to work on a book with him on the Desert Fathers but this was not supported by his Order. However, they did work together on a discussion about knowledge and wisdom with particular reference to the Genesis narrative of the creation of man and woman. This was published in Zen and the Birds of Appetite. Merton paid Suzuki a visit at Columbia University in June 1964, one of the few times he left the grounds of Gethsemane, and he was very impressed with his encounter. 
(The Declaration on the Relationship of the Church to Non-Christian Religions) and Unitatis Redintegratio (Decree of Ecumenism) both encourage learning from the Other in a spirit of co-operation and mutual understanding. But I think Merton's witness went much further and deeper than the Council's recommendations and reflects something of John Dunne's now famous notion of "passing over" into another religion followed by a return. ${ }^{15}$ This entails the willingness to participate in another person's religion while still remaining loyal to one's own, as well as acknowledging that the perception and understanding of one's own religion will be enhanced and changed by such encounters. This search for insights of truth within other religions is largely existential for Merton and never simply an exercise in obtaining information or learning facts. Merton knows that it is necessary to "drink from ancient sources of monastic vision and experience" (Asian Journal 312) if greater understanding is to be achieved, and his Asian journey allowed him the opportunity to do this at first hand; one consequence was that it gave him the possibility of becoming "a better and more enlightened monk" (313).

In the pages of his Asian Journal, there is never any proselytizing, only a genuine openness to the contemplative path across religious traditions. In this we read a text for our own time as it encourages us to eradicate our own gnawing "differentiations." ${ }^{16}$ Seeing beyond such differentiations is not easily achieved unless there is a willingness to experience at first hand "the true monastic conditions of quiet, tranquility, sobriety, leisureliness, reverence, meditation, and cloistered peace" (313). This is not a matter of learning about Asian traditions, but of integrating meditatively their insights into our own consciousness. It is clear that in the Buddha figures

${ }^{15}$ Dunne argues that it is necessary to actually participate in another person's religion if one is to understand it to any substantial degree. Like Merton, Dunne acknowledges that observer participation is one of the best ways of absorbing another faith into one's consciousness. This does not entail a call for conversion, but rather a willingness to absorb as far as possible another religious position and then return to one's own enriched. Paul Knitter draws from and extends this notion in his latest book.

${ }^{16}$ Besides the obvious example given by Merton to engage fully in another person's religion, I think the unique literary genre of the journal itself offers a helpful guide on and reflection of much contemporary experience for those willing to be open to its riches. For example, many people today, even if they do not belong to or believe in a particular religion, still encounter-sometimes brief, sometimes unexpected-insights into religion either through chance meetings with others of faith or through coming across extracts from religious texts. The cumulative effect of such human and textual encounters might never be empirically verified, but an enrichment of human life itself may take place as the wisdom of the great religions becomes imparted in this ad hoc, but potentially effective, way. 
at Polonnaruwa, Merton "discovered" something distinctly Asian in their emptiness and compassion, an insight which he claimed needed to be recognised by Westerners and indeed all peoples (237); he believed that non-hurrying and patient waiting, so characteristic of Asian forms, has much to teach the West.

Many of Merton's revelations could never have been achieved without a lifetime dedicated to contemplation and a focus on a heart that listens and receives. What remains after reading his journal is a glimpse into what a monk's life, lived with sincerity and discipline, can achieve. The joint Pontifical Statement of 1990, Dialogue and Proclamation, endorses the view that dialogical encounter may be the lever to give up engrained prejudices, revise preconceived ideas and allow understandings of faith to be purified. Merton had recognized all this much earlier in the 1960s, but went even further in his endorsement. He was convinced that "communication in depth across the lines which have hitherto divided religious and monastic traditions, is not only possible and desirable, but most important for the destinies of Twentieth-Century man" (313). In other words, there is a moral and spiritual imperative to engage actively and profoundly with the riches other traditions offer. This is what his Asian journey allowed him to do. It allows the reader the same opportunity.

What Merton recognized was the imperative of bringing the insights of other religions into one's own tradition. His monastic training allowed him to discern these insights. ${ }^{17}$ One example is Merton's response to the Buddhist notion of compassion which he unfolds in his final talk as being associated with the idea of inter-dependence. When the monk begs from the lay person he is not acting selfishly, instead "He is simply opening himself in this interdependence, this mutual inter-dependence, in which they recognize that they all are immersed in illusion together, but that the illusion which is also an empirical reality ... and that in this illusion, which is nevertheless empirically real, nirvana is present and it is all there, if you but see it" (242). Merton then reflects back on his own Christian tradition and comments, "I think ... this is very close to the Christian view of reality. It is the view that if you once penetrate by detachment and purity of heart to the inner secret of the ground of your ordinary experience, you attain to a liberty no-one can touch, that no-body can affect, that no political change of circumstances can do anything to" (242).

${ }^{17}$ See Knitter's and Clooney's recent works in relation to Christian self-understanding, with reference to insights from other world faiths. 
As we have seen, Merton was never interested in superficial pleasantries between religions. What he wished for was the reclaiming of a metaphysical consciousness rooted in an ontology which collapses any subject-object distinction (Zen and the Birds 23). He believed that underlying any subjective experience was "an immediate experience of Being" (23). Different from self-consciousness, this is "an immediate experience which goes beyond reflexive awareness. It is not 'consciousness of' but pure consciousness in which the subject as such "disappears"' (24). After quoting St. Paul's teaching "There is no longer Jew or Greek, there is no longer Jew or Gentile," he adds, "There is no longer Asian or European for the Christian. ... So while being open to Asian cultural things of value and using them, I think we also have to keep in mind the fact that Christianity and Buddhism, too, in their original purity point beyond all divisions between this and that" (340).

This non-dualist understanding of Merton was reinforced by his Asian trip. But he had come to understand this truth as early as March 18,1958 , the day when he experienced the oneness of all humanity in a Louisville shopping mall. As O'Connell comments, "As he saw these people moving in and out of stores, he was overwhelmed with the realization that he loved all these people and that they were neither alien to nor separate from him" (218). This sense of the unity of all peoples was also apparent after his meeting at Gethsemani in 1966 with the Vietnamese monk, Thich Nhat Hahn, after which he wrote the article, "Nhat Hahn Is My Brother." Merton believed the bond which was formed between them was representative of a wider trajectory of brotherhood and sisterhood, especially among the young, which was able to cut across all political, religious and cultural lines.

\section{"THE SELF IS NOT ITS OWN CENTRE"}

Perhaps more than anything else, what Merton wishes to communicate in his Asian writings and in his earlier writings, is that a new type of consciousness is likely to emerge in the light of deep encounters with other religions and Christian mysticism. What he endorses is that the self-aware subject is not final or absolute-rather, it is "a provisional self-construction which exists, for practical purposes, only in a sphere of relativity" (Asian Journal 24). It loses its meaning if it becomes fixated on itself; what is required is an awareness of a self which accepts its own dissolution through self-giving, letting go, and living in God. This is what the Christian life should primarily encourage-a being open to others 
since "the self is not its own centre and does not orbit around itself; it is centred on God, the one centre of all, which is 'everywhere and nowhere' in whom all are encountered, from whom all proceed. Thus from the start this consciousness is disposed to encounter 'the other' with whom it is already united anyway in God" (Zen and the Birds 24). Any intuition of Being necessarily includes what Merton calls "a ground of openness" (23). This is an ontological openness incorporating an infinite generosity that is never content with self-enclosure. It is a divine gift, not something to be acquired, and although it may lie dormant, is always present in the roots of each person's being. The key to understanding this notion is not to oppose it to more traditional understandings of Being, but to see it as expressing the same kind of consciousness in different, but complementary, ways. One of the main reasons why Merton was so attracted to Zen Buddhism was that it countered Roman Catholicism's pre-Vatican II emphasis on "doctrinal formulas, juridical order and ritual exactitude" (39). This tendency reduced the heart of Catholicism, which at its core, was centred around a living experience of unity. It was Merton's sincere hope that Vatican Council II would put an end to this kind of "obsessive tendency" (40).

As a monk, poet and theologian, Merton recognized that spiritual matters are best expressed and pondered through image, metaphor, and analogy, since they encourage the reader to understand who they are and what lies at the core of their humanity: "an ontological openness and an infinite generosity which communicates itself to everything that is" (25). Merton's continuing hope was that in the wake of Vatican Council II this kind of reality which is in fact a "taste and experience of eternal life" (39) might be encouraged and felt in this life. His encounter with Asian religions was crucial in assisting this ancient Catholic truth to become a reality. That is why, in my view, it is worth taking time to read his final reflections on this issue. But always, I would suggest, in a Merton-like way-slowly, meditatively and in a true monastic spirit.

\section{WORKS CITED}

\section{Works by Thomas Merton:}

Merton, Thomas. A Life in Letters: The Essential Collection. Ed. William H. Shannon and Christine M. Bochen. New York: Harper, 2008. Print.

---. Conjectures of a Guilty Bystander. New York: Doubleday, 1966. Print.

---. Contemplation in a World of Action. New York: Doubleday, 1971. Print. 
---. New Seeds of Contemplation. New York: New Directions, 2007. Print.

---. The Inner Experience: Notes on Contemplation. Ed. William H. Shannon. London: SPCK, 2003. Print.

---. The Sign of Jonas. New York: Harcourt, 1953. Print.

--- Zen and the Birds of Appetite. New York: New Directions, 1968. Print.

The Asian Journal of Thomas Merton. Ed. Naomi Burton, Patrick Hart and James Laughlin.

New York: New Directions, 1975. Print.

\section{Other Works:}

Aguilar, Mario I. Thomas Merton: Contemplation and Political Action. London: SPCK, 2011. Print.

Benedict XVI. "Lectio Divina" (Address to the International Congress on the $40^{\text {th }}$ Anniversary of Dei Verbum, 2005). Bulletin Dei Verbum 76/77 (2005): 5. Print.

Casey, Michael. Strangers to the City: Reflections on the Values of the Rule of St. Benedict. Brewster, MA: Paraclete, 2005. Print.

Chittister, Joan. The Rule of St. Benedict: Insight for the Ages. Slough: St. Paul's, 1992.

Clooney, Francis. Comparative Theology: Deep Learning Across Religious Borders. Chichester: Wiley, 2010. Print.

Cunningham, Lawrence. Thomas Merton and the Monastic Vision. Grand Rapids: William B. Eerdmans, 1992. Print.

Dunne, John. A Search for God in Time and Memory. London: Macmillan, 1969. Print.

Ford, Michael. Spiritual Masters For All Seasons. New Jersey: Hidden Springs, 2009. Print.

Foster, David. Deep Calls to Deep: Going Further in Prayer. London: Continuum, 2007. Print.

---. Reading with God: Lectio Divina. London: Continuum, 2005. Print.

Harris, Elizabeth. Buddhism for a Violent World: A Christian Reflection. London: Epworth, 2010. Print.

Hart, Patrick and Jonathan Montaldo, eds. The Intimate Merton: His Life from His Journals. New York: Harper, 1999. Print.

Howe, Jean-Marie. Secret of the Heart: Spiritual Being. Kalamazoo, Cistercian, 2005. Print.

Knitter, Paul. Without Buddha I Could not be a Christian: A Personal Journey of Passing Over and Passing Back. Oxford: Oneworld, 2009. Print.

Masini, Mario. Lectio Divina: An Ancient Prayer that is Ever New. Trans. Edmund C. Lane. New York: Alba House, 1998. Print.

Mott, Michael. The Seven Mountains of Thomas Merton. London: Sheldon, 1986. Print. O'Connell, Patrick, ed. The Vision of Thomas Merton. Indiana: Ave Maria, 2003. Print. Pontifical Council for Inter-religious Dialogue. Dialogue and Proclamation. The Holy See, 19 May 1991. Web. 8 Jul. 2011. <http://www.vatican.va/>.

Shannon, William H. Thomas Merton: An Introduction. Cincinnati: St. Anthony Messenger, 2005. Print. 
Shannon, William H., Christine M. Bochen, and Patrick F. O'Connell, eds. The Thomas Merton Encyclopedia. New York: Orbis, 2002. Print.

Thich Nhat Hahn. Essential Writings. Ed. Robert Ellsberg. London: Darton, 2008. Print.

Torevell, David."Circles of Meaning: The Christian Dynamic of Contemplation, Meaning and Purpose." Journal of Christian Education 49.3 (2006): 33-42.

---. "Learning from the Buddhist Sangha: How New Trajectories in Christian Spirituality Might Draw from the Heritage of Theravada Buddhism." International Journal for the Study of the Christian Church 7.3 (2007): 210-27.

David Torevell is Associate Professor in Christian theology and Co-Director of the Centre for Christian Education at Liverpool Hope University, UK. He has published two monographs, Losing the Sacred: Ritual, Modernity and Liturgical Reform (T\&T Clark, 2000) and Liturgy and the Beauty of the Unknown: Another Place (Ashgate, 2007). He has edited numerous books and is presently series editor of the Liverpool Hope University Studies in Ethics Series. He teaches courses on Christian theology, religious and philosophical aesthetics and education. His research interests include Christian-Buddhist dialogue, Christian monasticism, Christian worship and Christian education. He is presently researching the theology of the Christian virtues and vices in early and contemporary monasticism (East and West) and examining their artistic representation. 